\title{
SUPERAGING - SPOLEČNOST A LIDÉ: ÚVOD DO PROBLEMATIKY
}

Hana Georgi, Zuzana Frydrychová

\begin{abstract}
Abstrakt
V posledních letech se můžeme v gerontologické literatuře setkat s novými termíny reflektujícím jevy nové či nově sledované. Mezi tyto termíny patři tzv. „SuperAging“. Tato stat' seznamuje čtenáře s obsahem termínu ve dvou hlavních souvislostech: 1) v rámci společnosti - sociologie a demografie, 2) v rámci neuropsychologie a kognitivního stárnutí jedinců. Cílem je rozš́rrit tyto pojmy a jejich obsah mezi českou psychologickou obec.
\end{abstract}

Klíčová slova: stárnutí, demografie, dlouhověkost, kognice

\section{SUPERAGING - SOCIETIES AND INDIVIDUALS: INTRODUCTION}

\begin{abstract}
Novel terms have been introduced in gerontology, reflecting new or newly observed phenomena. ,SuperAging “ is one of those terms. This text introduces its content to the readers in the main areas of interest: 1) societal view of sociology and demography, 2) neuropsychology and cognitive ageing of individuals. Our goal is to make the aspects of SuperAgeing familiar to Czech psychologists.
\end{abstract}

Keywords: ageing, demography, longevity, cognition

Došlo: 8. 4. 2020

Schváleno: 17. 4. 2020 


\section{SuperAging společnost}

Stárnutí společnosti je v posledních letech zmiňované stále častěji, a to především v souvislosti se změnami a výzvami, které tento demografický vývoj s sebou nese. Jde o celosvětový trend, nicméně některé státy mají podíl starších obyvatel mnohem vyšší než jiné (UN, Department of Economic and Social Affairs, Population Division, 2019b). Podle podílu starších osob ve věku 65 a více let (tj. dle ,indexu stárnutí“ (srov. Valaoras, 1950)) se můžeme v odborných i populárních sděleních setkat s termíny jako aging, aged, super-aged a hyperaged society, tj. stárnoucí, zestárlá, velmi zestárlá neboli super-zestárlá či hyper-zestárlá společnost.

V tomto textu se budeme držet anglických termínů. Cowgill \& Holmes (1972) navrhli klasifikaci společností podle podílu seniorů na společnosti mladé / young (do $7 \%$ ), dospělé / mature (7-9,9 \%), zestárlé / aged (nad $10 \%)$. Andrews a Phillips (2005, s. 43) rozlišují další dvě kategorie super-aged (20-29,9 \%) a dokonce hyper-aged (30+ \%). V pracích převážně asijské provenience, ale i v reportech mezinárodní ratingové agentury Moody`s se setkáváme se zmínkami o definicích Spojených národů (UN) či Světové zdravotnické organizace (WHO) pro stárnoucí / ageing společnosti (7 \% seniorů), zestárlé / aged (14\%) a super-aged či superaging (20 nebo $21 \%$ ) (Lu, 2017). Př́kladem super-aging společnosti je Japonsko, kde kolem roku 2030 prognózy hovoří o třetině seniorů v populaci (Muramatsu \& Akiyama, 2011). Superaged společností je mj. také Německo a Singapore. V posledních letech mezi tzv. zestárlé společnosti (aged society), u nichž je podíl seniorů v populaci vyšší než 14 \%, vstoupily Taiwan a Jižní Korea. Zmíněné definice se autorkám nepodařilo dohledat v žádných primárních zdrojích UN nebo WHO.

Celosvětový trend podílu osob ve věkové skupině 65 a více let (65+) je vzestupný, od 1 člověka ze $17 \mathrm{v}$ roce 1990, přes 1 z 11 v roce 2019 až po projekci 1 ze 6 v roce 2050 (UN, Department of Economic and Social Affairs, Population Division, 2019a). Statistické údaje v ČR potvrzují, že se nejvyšší prŕrůstky v počtu obyvatel koncentrují ve věkové skupině 65+ (Aktuální populační vývoj v kostce, 2020). Konvenční způsob pohledu na ukazatel starobní závislosti (oldage dependency ratio) založený na chronologickém věku (poměr osob ve věku 65+ ku počtu osob ve věku 20-64 let) není př́liš vhodný s ohledem na významné rozdíly mezi jednotlivými regiony v délce dožití, kvalitě života ve stáří, péči o seniory, prřijmech, riziku chudoby aj. Proto se postupně mění pohled na tuto problematiku a zvažují se jiné přístupy. Na příklad př́istupy založené na prospektivním věku (předpokládané zbývající roky života), které by znamenaly dynamický práh „stáří“. Tento odvozený ukazatel prospektivní starobní závislosti roste celosvětově pomaleji (UN, Department of Economic and Social Affairs, Population Division, 2019a). Ilustrací rozdílů v rámci Evropské Unie jsou data o zaměstnanosti lidí ve věkové kategorii $65+$, a to od 1,6 \% ve Španělsku po 11,7 \% v Portugalsku (v roce 2014). Evropský průměr byl na $5,3 \% \mathrm{~s}$ ČR $(4,9 \%)$ těsně pod průměrem. Téměř polovina pracujících v této věkové kategorii pracovala na plný úvazek, těsně nadpoloviční většina jako OSVČ. Cca $20 \%$ pak pracuje v zemědělství (Federal Statistical Office, 2016). 


\section{Dlouhověkost}

Stárnutí společnosti se jednak rovná nárůstu počtu osob ve vyšším věku (a tím i jejich podílu v populaci), ale také prodlužování lidského života. Každý normálně stárnoucí organismus, i člověk, prochází involučním procesem. Negativní jevy, se kterými se během života setkal jako nemoci, stres, úrazy, si vybírají daň. Hromadí se chyby v přepisování genetického kódu, tělesné i duševní síly postupně uvadají, zpomalují se procesy hojení a obnovy, dochází k úbytku tkání, člověk je více náchylný k onemocněním, nebot' i imunitní systém je slabší (Taffet, 2019). Nicméně, tento proces je značně individuální a jeho průběh je dán genetickými faktory, prostředím i životním stylem. Nárůst počtu osob dožívajících se sta let a více umožnil důkladnější výzkum dlouhověkosti. V současné době panuje názor, že do 70-80 let věku je hlavním determinantem zdraví a délky dožití životní styl. Poté začíná převažovat dědičná složka (Passarino et al., 2016). Průkopníkem studia dědičnosti dlouhověkosti byl Tom Johnson, který koncem 80. let XX. století publikoval studie genetických analýz hád'átka obecného (Johnson, 1987). V současnosti se studiem dlouhověkosti zabývá řada center i dílčích studií po celém světě včetně České republiky. Například na Fakultě humanitních studií Univerzity Karlovy pod vedením doc. MUDr. Ivy Holmerové, Ph.D. je to Centrum pro studium dlouhovékosti a dlouhodobé péče FHS UK (CELLO, b.r.).

Mezi geograficky ohraničené anomálie - "modré zóny", místa, kde se lidé dožívají nadprůměrného věku, patří ostrovy Okinawa (Japonsko), Ikaria (̌̌ecko), Nicoya Peninsula (Kostarika), Sardinie (Itálie), a Loma Linda (Kalifornie, USA) (Buettner \& Skemp, 2016).

\section{Dobré stárnutí}

Délka života samotná není asi pro nikoho z nás jediným měřítkem kvality života. Výzkumy i průzkumy v rozvinutých státech se vzácně shodují na nejčastěji udávané preferované délce života 80 let (Duncan, 2012; Lang et al., 2007). Může se to zdát málo. Očekávaná délka života celosvětově je kolem 73 let, ale mezi opačnými póly spektra stojí 30 let. Nejdéle se doživají lidé v Hong Kongu (85 let) a nejkratší život lze očekávat ve Středoafrické republice (54 let) (Life Expectancy of the World Population, b.r.). Důvodem pro de facto zkrácení ideální délky života na 80 let v rozvinutých zemích může být asociace nejvyššího věku se zdravotními obtížemi, křrehkostí a nesoběstačností a nízkou kvalitou života (Lang et al., 2007). Lidé si zřejmě přejí sami uniknout tomu, s čím se během života setkávají, a nepřejí si sami zažít: dlouhou dobu závislosti obtěžující okolí, život udržovaný dlouho v bolesti až utrpení (Brown, 2015) (viz níže - DALY). Faktory, od nichž lidé odvozují celkovou kvalitu života, se důrazem mění v závislosti na věku, ale v podstatě jsou univerzální pro všechny: fyzické a duševní zdraví, emoční well-being, finanční zdroje, sociální vztahy, společenská aktivita a prostředí (Vaarama, 2009). S těmito faktory se zároveň můžeme setkat v definicích úspěšného stárnutí podle WHO, jež se jen mírně liší od původního biomedicínského modelu Rowe a Kahna z roku 1987: absence nemoci, vysoká úroveň kognitivních funkcí a aktivní zapojení do života. Tomuto modelu ovšem bylo vytýkáno, že se týká jen hrstky elitních seniorů, protože z úspěšného stárnutí vylučuje lidi trpící chorobami, kterých je ve starším věku většina (Lowry et al., 2012). Baltesovi pak přišli s ekologicky pojatou definicí úspěšného stárnutí založeného na přizpůsobení se - optimalizaci vlastních zdrojů a kompenzaci svých omezení (Baltes \& Baltes, 1990). 
Nověji je propagováno “Zdravé stárnutí”, které dle WHO zahrnuje jak kapacity jedince, tak jeho prostředí, a je to "proces rozvoje a udržování funkčních schopností, které umožní wellbeing/pohodu ve starším věku". Mezi funkční patří schopnost plnit své základní potřeby, učit se, rozvíjet se a dělat rozhodnutí, mobility, budovat a udržovat vztahy a přispívat něčím společnosti (World Health Organization, 2015). Na společenské úrovni byl v Evropě pro porovnání míry, do jaké starší lidé od 55 do 74 let mohou realizovat svůj plný potenciál, vytvořen Index aktivního stárnutí (Active Aging Index, AAI) (UNECE / European Commission, 2019). AAI je založen na národních statistikách a zahrnuje celkem 22 ukazatelů. Mezi nimi jsou ukazatele zaměstnanosti, dobrovolnické aktivity, péče o děti a vnoučata, tělesného cvičení, celoživotního učení, fyzické bezpečnosti, využívání informačních a komunikačních technologií, očekávaný věk dožití v 55 letech a další (Čepelka, 2018). Přestože definic úspěšného stárnutí a jeho ekvivalentů (optimální, elitní, zdravé, aktivní, atd.) je mnoho, v naprosté většině se objevuje funkční samostatnost, nezávislost či disabilita jako jeden z parametrů (Lowry et al., 2012; Nyberg \& Pudas, 2019). Jako jedno ze standardních měřítek se užívají „Roky života vážené disabilitou“ (Disability-Adjusted Life Years (DALY)) - čili ztracená léta života $v$ důsledku nemoci (Kř́̌ž, 2016). DALY 1 si můžeme představit jako jeden rok ztraceného „zdravého“ života. Celosvětová data o DALY hovoří o 2500000 tisících letech ztracených v důsledku nemocí na světě v roce 2017; v globálu jsou sice největším viníkem přenosné choroby a neonatální poruchy, ovšem ve vyspělých státech s vysokým sociodemografickým indexem jsou to civilizační chronická onemocnění (Kyu et al., 2018). Proto nepřekvapí, že podíl na DALY v Evropské unii mají právě chronická onemocnění ( 87 \% DALY), z nichž ponejvíce ischemická choroba srdeční (EU Science Hub, 2020). Komplementární metrikou k DALY jsou HALE - Healthy Life Expectancy, tedy počet let ve zdraví.

Mezinárodní studie Global Burden of Diseases, Injuries, and Risk Factors Study porovnávající světová data ukázala kromě rozdílů mezi zeměmi dle jejich socio-demografického indexu, také na rozdíly mezi pohlavími (př́klad viz tabulka 1 a 2). Vidíme, že dochází k prodlužování celkové délky života i délky života ve zdraví. Přičemž $\mathrm{k}$ největšímu skoku v délce života ve zdraví u narozených došlo mezi lety 1990 a 2017 u mužů.

$\mathrm{Z}$ dostupných dat je zřejmé, že je nutné soustředit se na preventivní opatření a determinanty zdraví (Kyu et al., 2018). V tabulkách 1 a 2, kde je jen několik prŕíkladů vidíme nárůst očekávané délky života i let prožitých ve zdraví. Je patrné, že se neočekává, že přidané roky života budou prožité ve zdraví (rozdíl mezi lety 1990 a 2017 v očekávané délce života je větší než rozdíl HALE mezi těmito lety). 
Tabulka 1. Očekávaná délka dožití a HALE při narození v letech 1990 a 2017

\begin{tabular}{|l|r|r|r|r|r|r|r|r|r|r|r|r|}
\hline & \multicolumn{2}{|c}{ Očekávaná délka dožití } & \multicolumn{4}{c|}{ HALE } & \multicolumn{4}{|c|}{ Rozdíl } \\
\hline & \multicolumn{2}{|c|}{ Ženy } & \multicolumn{2}{c|}{ Muži } & \multicolumn{2}{|c|}{ Ženy } & \multicolumn{2}{c|}{ Muži } & \multicolumn{2}{|c|}{ Ženy } & \multicolumn{2}{|c|}{ Muži } \\
\hline Země & 1990 & 2017 & 1990 & 2017 & 1990 & 2017 & 1990 & 2017 & ODŽ & HALE & ODŽ & HALE \\
\hline $\begin{array}{l}\text { Česká } \\
\text { republika }\end{array}$ & 75,5 & 82,0 & 67,6 & 76,3 & 64,7 & 69,6 & 58,9 & 65,1 & 6,5 & 4,9 & 8,7 & 6,2 \\
\hline Slovensko & 75,5 & 80,6 & 66,7 & 74,1 & 64,9 & 68,9 & 57,9 & 63,7 & 5,1 & 4 & 7,4 & 5,8 \\
\hline Mad’arsko & 73,9 & 80,2 & 65,3 & 73,2 & 62,9 & 68,3 & 56,6 & 63,1 & 6,3 & 5,4 & 7,9 & 6,5 \\
\hline Německo & 78,6 & 83,0 & 72,1 & 78,2 & 67,4 & 70,8 & 63,5 & 68,0 & 4,4 & 3,4 & 6,1 & 4,5 \\
\hline USA & 79,0 & 81,1 & 72,1 & 76,1 & 66,8 & 67,9 & 62,6 & 65,3 & 2,1 & 1,1 & 4 & 2,7 \\
\hline Japonsko & 82,2 & $\mathbf{8 7 , 2}$ & 76,2 & $\mathbf{8 1 , 1}$ & 71,2 & $\mathbf{7 4 , 6}$ & 68,0 & $\mathbf{7 1 , 4}$ & 5 & 3,4 & 4,9 & 3,4 \\
\hline
\end{tabular}

Pozn.: ODŽ - očekávaná délka života. HALE - počet let ve zdraví. V tabulce jsou uvedeny průměrné hodnoty. Převzato z Kyu et al., 2018.

Tabulka 2. Očekávaná délka dožití a HALE ve věku 65 let v letech 1990 a 2017

\begin{tabular}{|l|c|c|c|c|c|c|c|c|}
\hline & \multicolumn{3}{|c|}{ Očekávaná délka dožití } & \multicolumn{4}{c|}{ HALE } \\
\hline & \multicolumn{2}{|c|}{ Ženy } & \multicolumn{2}{c|}{ Muži } & \multicolumn{2}{c|}{ Ženy } & \multicolumn{2}{c|}{ Muži } \\
\hline Země & 1990 & 2017 & 1990 & 2017 & 1990 & 2017 & 1990 & 2017 \\
\hline Česká republika & 15,3 & 19,8 & 11,6 & 16,3 & 10,6 & 13,9 & 8,1 & 11,2 \\
\hline Slovensko & 15,8 & 19,0 & 12,2 & 15,4 & 11,2 & 13,5 & 8,6 & 10,7 \\
\hline Mad'arsko & 15,5 & 19,1 & 12,1 & 15,0 & 10,5 & 13,4 & 8,4 & 10,5 \\
\hline Německo & 17,7 & 20,8 & 14,1 & 17,8 & 13,3 & 15,5 & 10,7 & 13,4 \\
\hline USA & 19,1 & 20,6 & 15,3 & 18,1 & 14,1 & 14,7 & 11,2 & 12,9 \\
\hline Japonsko & 20,3 & 24,4 & 16,4 & 19,7 & 15,6 & $\mathbf{1 8 , 5}$ & 12,8 & $\mathbf{1 5 , 1}$ \\
\hline
\end{tabular}

Pozn.: ODŽ - očekávaná délka života. HALE - počet let ve zdraví. V tabulce jsou uvedeny průměrné hodnoty. Převzato z Kyu et al., 2018.

S funkční samostatností kromě fyzické kondice úzce souvisí stav kognice (Ganguli et al., 2010). Proto se především v posledních letech výzkumné studie zabývají kognitivními schopnostmi v kontextu, byt' panuje velká heterogenita v př́stupech (Mana \& Bezdicek, in press). 


\section{Úspěšné stárnutí kognice}

Úspěšné stárnutí se po půl století zájmu ze strany psychologů a gerontologů dostalo do centra pozornosti také v neurovědách (Nyberg \& Pudas, 2019). Klinický výzkum se logicky věnoval nejprve tíživým stránkám, nemocem a poruchám, tj. $\mathrm{v}$ př́padě stárnutí a stáŕí tedy věkempodmíněným jako jsou chronická neinfekční onemocnění, neurodegenerativní onemocnění, kognitivní poruchy a demence. Druhý pól kontinua kognitivního stárnutí zůstával spíše nepovšimnut, přestože již v roce 2002 byl Yaakovem Sternem představen koncept kognitivní rezervy. Kognitivní rezerva je schopnost na behaviorální úrovni kompenzovat involuční až patologické změny mozku. Někteří autoři hovoří o mozkové rezervě, která je snadno kvantifikovatelná na strukturálních zobrazeních mozku, oproti kognitivní rezervě, pro kterou se hůřre hledají anatomické koreláty (Cabeza et al., 2018). V míře kognitivní rezervy se lidé liší. Někteří mají i přes známky strukturálního poškození mozku kognitivní výkony zcela normální. Na tuto zvláštnost - např́klad na "klinicky tichou Alzheimerovu chorobu" poukázaly mj. studie v rámci Nun Study (Iacono et al., 2009) nebo Neuropathology Group of the Medical Research Council Cognitive Function and Ageing Study (MRC CFAS) (2001). Nun Study je dlouhodobá studie sledující jeptišky řádu School Sisters of Notre Dame Congregation v USA od roku 1986, s řadou navazujících výzkumů (Hack et al., 2019; Snowdon, 2003). Postupně se zájem vědců přesunul tedy i k lidem, jejichž kognitivní výkony vzdorují běhu času a stárnutí. Žrejmě i díky tradici výzkumů stárnutí a neurodegenerativních onemocnění a významu paměti pro funkční soběstačnost se v současnosti nejvíce setkáme s výzkumy odolné epizodické paměti. Způsobů, jak definovat takovou odolnost, je samožrejmě mnoho, stejně tak termínů označujících takové jedince. Pro určení osob s nad-průměrnou pamětí ve starším věku se užívají hlavní dva postupy: 1) srovnání v rámci své věkové kohorty se stanoví určitý práh nad průměrem výkonu v testu deklarativní/epizodické paměti (Yu et al., 2019). 2) jako práh se určí průměrný výkon v daném testu mladší populace (např. o 20 let mladší) (Harrison et al., 2012).

Užití normativních údajů v rámci své věkové skupiny a souboru může omezit zkreslení dané kohortovými rozdíly, Flynnovým efektem (Salthouse, 2015). Flynnovým efektem je nazýván jev vypozorovaný z porovnání výsledků kognitivních testů v různých generacích (Flynn, 1987). Tato srovnání jsou umožněna dlouhou, přibližně stoletou, historií testování kognice a dostupnosti datových souborů. Ukazuje se, že generace narozené a testované dříve dosahovaly nižších výkonů. Tento jev byl ve vědeckých pracích zmiňován již od poloviny třicátých let XX. století (Lynn, 2013). Zdrojů pro tyto rozdíly může být více, např́íklad systém a dostupnost vzdělávání. Flynnův efekt ovšem hraje i roli při užití starších norem pro danou věkovou skupinu na současné generace. $\mathrm{V}$ českém prostředí jsou normy kognitivních testů pro populaci ve věku 60 - 90 let dostupné z nedávné doby, povětšinou z Národní normativní studie kognitivních determinant zdravého stárnutí - NANOK, realizované v letech 2012-2015 (Štěpánková et al., 2015). Je možné předpokládat, že zkreslení by při jejich použití tedy v současné době bylo spíše menší.

Větší popularity doznal př́istup druhý, tedy “mladá pamět”" a normální ostatní kognitivní funkce vzhledem $\mathrm{k}$ věku. Důsledně se pamětí odolnou proti stárnutí zabývají v Northwestern University v Chicagu, USA, kde zpopularizovali termíny "SuperAging" pro jev a "SuperAger" pro jedince (Harrison et al., 2012; Rogalski et al., 2013). Jejich definici pak převzaly týmy 
v jiných institucích a zemích včetně ČR. Díky tomu je pak možné data různých studií adekvátně porovnávat (Borelli et al., 2018). Operacionalizovat tedy můžeme definici SuperAgerů takto: osoby ve věku 80 a více let, jejichž výkon ve volném oddáleném vybavení Philadelfského verbálního testu učení PVLT je přinejmenším na úrovni průměrného výkonu osob ve věku 60-65 let (tj. . 9) a výkony v nepamětových testech (Test cesty, Bostonský test pojmenování a kategorická verbální fluence - zvířata) není horší než jednu standardní odchylku pro vlastní věkovou kategorii 80+ let. Pro srovnání: průměrný skór pro věkovou kategorii 80+ v PVLT je 7 slov (Bezdicek et al., 2014). SuperAgerů je dle dostupných studií ve své věkové populaci 17-35 \% (Červenková et al., 2020; Harrison et al., 2018; Saint Martin et al., 2017). Častěji jsou SuperAgery ženy, což může souviset s lepším výkonem v pamět’ových testech v porovnání s muži a s faktem, že ženy se dožívají v průměru vyššího věku než muži. Souvislost statusu SuperAgera s vyšší úrovní vzdělání nebyla dosud spolehlivě prokázána (Harrison et al., 2018; Sun et al., 2016).

Kognitivní výkon SuperAgerů není superiorní pouze v pamět'ových testech při opakovaném sledování; dle Harrison et al. (2018) se jejich výkon v jiných zkoumaných kognitivních doménách (pracovní pamět', rychlost zpracování informací) sice zhoršoval podobně jako u normálně stárnoucích osob, i tak byl na lepší úrovni.

Biologické souvislosti SuperAgingu se teprve postupně stávají námětem studií. Byly popsány strukturální rozdíly v mozcích SuperAgerů oproti kontrolám (Gefen et al., 2015; Rogalski et al., 2015, 2018), méně depozit beta-amyloidu či tau proteinu, tj. mozkomíšních biomarkerů typických pro Alzheimerovu nemoc (Gefen et al., 2015; Rogalski et al., 2013). Výčet současných trendů ve výzkumu biologických znaků v tomto kontextu byl publikován např. v Psychiatrii pro praxi (Kopeček et al., 2020). Nové směry bádání mohou navazovat na obdobné výzkumy druhého pólu kognitivního stárnutí - syndromu demence. Můžeme tedy očekávat na příklad výzkumy SuperAgingu zkoumající střevní mikrofloru - mikrobiom, chronickou peridontitidu (srov. Dominy et al., 2019; Wang et al., 2019), roli glymfatických funkcí - transportního systému v mozku (Schneider \& Viswanathan, 2019), zánětlivých procesů a oxidativního stresu (Bott et al., 2017; Mapstone et al., 2017), spánku (Mander et al., 2017).

Dalším zdrojem rozdílů mezi studiemi kognitivního stárnutí je volba průřezových dat anebo longitudinální sledování. Tradiční studie stárnutí po celém světě mají př́stup k velkým datovým souborům, které jsou mimořádně cenné, nebot' umožňují sledovat trajektorie v čase a odvozovat hypotézy o projektivním vlivu různých jevů včetně životního stylu. V longitudinálních studiích se pak můžeme setkat s pojmy jako „decliners“ - označující osoby, u kterých došlo během let k definovanému poklesu kognice; „,maintainers“ - pro osoby, jejichž mozek si od mládí až po vysoký věk dokáže uchovat, a to včetně průběžných „oprav“, stejnou úroveň neurálních zdrojů a potažmo kognitivních výkonů; a ,averages“ - osoby, u nichž nedošlo k tak výraznému poklesu, aby byly označeny jako decliners, ale zároveň se neudržely v pásmu stabilních výkonů (Cabeza et al., 2018; Josefsson et al., 2019). Ovšem, stabilní výkony nemusí být po celou dobu nijak vysoké. O stabilitě nadprůměrných výkonů u tak zvaných SuperAgers je zatím velmi málo dostupných údajů. Ve studii NANOK se ukázalo, že po třech letech bylo $12 \%$ osob stabilními SuperAgery (Červenková et al., 2019). 
Se stejnou metodologickou otázkou ve smyslu průřezových a longitudinálních dat se setkáváme i ve studiích hledajících biologické markery stárnutí. Nedávno publikovaná studie určila při dlouhodobém sledování čtyři hlavní typy lidského stárnutí „ageotypes“ podle molekulárních změn, které reflektují životní styl, zdravotní anamnézu, a to se zrychleným stárnutím imunity, ledvin, jater a metabolismu. Autoři očekávají, že další studie s většími soubory najdou více distinktivních ,ageotypů“ (Ahadi et al., 2020).

\section{Životní styl a SuperAging}

Dle aktuálních poznatků deskriptivních studií víme, že u SuperAgerů nalézáme častěji některé charakteristiky a znaky životního stylu. Jednak jde o vyšší vzdělání, duševně náročné zaměstnání a volnočasové aktivity, často zmiňované jako preventivní proti demenci či proxy pro kognitivní rezervu (Hahn \& Lee, 2019). Nicméně, protektivní efekt vyššího vzdělání není zcela objasněn (Nyberg \& Pudas, 2019). Zřejmě záleží mnohem více na dalším kontextu jako je vzdělávání v raném věku (Zahodne et al., 2015). Podobně nejasná je i role duševně náročné práce či koníčků. Je možné, že protektivně fungují po dobu působení nikoli posléze po jejich ukončení (např. odchodu do penze) (Finkel et al., 2009). Mezi další patří učení se novým věcem a kladení si výzev znamenajících určitou námahu, pro jejichž dosažení je nutné překonat vlastní pohodlnost a zajeté koleje (Lindquist et al., 2016). Pro SuperAgera je více obvyklé mít pevnou sociální sít' - přátele, k nimž má důvěru, že pomohou, pokud bude pomoc potřebovat (Cook Maher et al., 2017).

Příčinné vztahy dosud nejsou objasněny. Není možné tvrdit, že určitá opatření životního stylu $\mathrm{s}$ jistotou povedou ke kognitivně úspěšnému stárnutí, např. ve smyslu definice SuperAgingu. WHO (2019) se vyjadřuje opatrně dokonce i ve formulaci preventivních doporučení pro mnohem déle zkoumanou oblast kognitivního poklesu či demence. Nikomu ovšem neuškodí se jimi řídit při vlastní snaze stárnout co nejlépe. Nejsilnější podporu ve vědeckých zjištěních (nejvíce „evidence-based“) má jako prevence fyzická aerobní aktivita střední intenzity (kdy člověk zvládne při pohybu ještě mluvit - „Talk test“ (Goode, 1978)) v celkovém čase alespoň 2,5 hodiny týdně. Mezi dalšími pak jmenujme omezení kouření a stravu podobnou středomořské (World Health Organization, 2019). Souvislost dlouhodobé adherence k dietě „MIND“ byla zdokumentována s pomalejším kognitivním poklesem (Morris et al., 2015) nebo lepší epizodickou pamětí u žen seniorského věku (Berendsen et al., 2018). Dieta MIND (Mediterranean-DASH Intervention for Neurodegenerative Delay) je odvozená od středomořské stravy a diety proti vysokému tlaku (DASH; Dietary Approaches to Stop Hypertension) a mj. klade důraz na potraviny rostlinného původu, a to především zelenou listovou zeleninu a drobné plody (bobule a souplodí peckoviček, tj. borůvky, jahody, atd.), dále sníženou spotřebu živočišných produktů a vysoce nasycených tuků (Morris et al., 2014). Zároveň, výše zmiňovaná doporučení jsou obecně platná jako prevence vedoucí k snížení rizik jiných chronických onemocnění včetně cukrovky (diabetes mellitus) II. typu, vysokého tlaku a onemocnění srdce, která mohou souviset s rozvojem neurodegenerativních onemocnění vedoucích k demenci (Gottesman et al., 2017). 
Z psychologie můžeme zmínit zjištění, že se repetitivní negativní myšlenky, ruminace a obavy dle Marchanta a Howarda (2015) podílejí na vzniku tzv. kognitivního dluhu, který zvyšuje riziko rozvoje Alzheimerovy demence u predisponovaných osob. Podle této hypotézy by osoby s množstvím neregulovaného stresu, s depresí, úzkostné, s poruchami spánku či posttraumatickou stresovou poruchou měly být populací pro cílená preventivní opatření. Nedávná studie poukázala na vliv proteinu REST (gen na 4. chromozomu), který reguluje prŕlišnou aktivaci neuronů. Př́lišná excitace nervové soustavy zřejmě zkracuje lidský věk (Zullo et al., 2019). Tento protein byl původně zkoumán v souvislosti s rakovinou a posléze s demencí a jinými chorobami a jeho protektivní rolí v stárnoucím mozku. Ukázalo se, že množství REST v plazmě je možné ovlivnit i psychologickou intervencí - mindfulness (Ashton et al., 2017). Teprve další výzkum ukáže, zda je hypotetická osa „mindfulness - regulace proteinu REST snížení excitace nervové soustavy - odolnost mozku proti úpadku stáří، platná.

Bude velmi zajímavé vidět výsledky studií zaměřených na životní styl, které lidem pomohou prodloužit léta prožitá ve zdraví, samostatně, a s kognicí na úrovni, jež je nebude omezovat v jejich spokojenosti, soběstačnosti a sociálním kontaktu.

Grantová podpora: Trénink vizuální selektivní pozornosti u seniorů (GA UK č. 899018)

\section{Literatura}

Ahadi, S., Zhou, W., Schüssler-Fiorenza Rose, S. M., Sailani, M. R., Contrepois, K., Avina, M., Ashland, M., Brunet, A., \& Snyder, M. (2020). Personal aging markers and ageotypes revealed by deep longitudinal profiling. Nature Medicine, 26(1), 83-90. https://doi.org/10.1038/s41591-019-0719-5

Aktuální populační vývoj v kostce. (2020). Český statistický úřad. https://www.czso.cz/csu/czso/aktualni-populacni-vyvoj-v-kostce

Andrews, G. J., \& Phillips, D. R. (2005). Ageing and place: Perspectives, policy, practice. Routledge. https://ezproxy.aub.edu.lb/login?url=https://www.taylorfrancis.com/books/97811343613 80

Ashton, N. J., Hye, A., Leckey, C. A., Jones, A. R., Gardner, A., Elliott, C., Wetherell, J. L., Lenze, E. J., Killick, R., \& Marchant, N. L. (2017). Plasma REST: A novel candidate biomarker of Alzheimer's disease is modified by psychological intervention in an at-risk population. Translational Psychiatry, 7(6), e1148. https://doi.org/10.1038/tp.2017.113

Baltes, P. B., \& Baltes, M. M. (1990). Psychological perspectives of successful aging: The model of selective optimisation with compensation. In P. B. Baltes, M. M. Baltes, \& European Science Foundation (Ed.), Successful aging: Perspectives from the behavioral sciences (s. 1-34). Cambridge University Press.

Berendsen, A. M., Kang, J. H., Feskens, E. J. M., de Groot, C. P. G. M., Grodstein, F., \& van de Rest, O. (2018). Association of long-term adherence to the mind diet with cognitive function and cognitive decline in American women. The Journal of Nutrition, Health \& Aging, 22(2), 222-229. https://doi.org/10.1007/s12603-017-0909-0 
Bezdicek, O., Libon, D. J., Stepankova, H., Panenkova, E., Lukavsky, J., Garrett, K. D., Lamar, M., Price, C. C., \& Kopecek, M. (2014). Development, validity, and normative data study for the 12-Word Philadelphia Verbal Learning Test [czP(r)VLT-12] among older and very old Czech adults. The Clinical Neuropsychologist, 28(7), 1162-1181. https://doi.org/10.1080/13854046.2014.952666

Borelli, W. V., Carmona, K. C., Studart-Neto, A., Nitrini, R., Caramelli, P., \& Costa, J. C. da. (2018). Operationalized definition of older adults with high cognitive performance. Dementia \& Neuropsychologia, 12(3), 221-227. https://doi.org/10.1590/198057642018dn12-030001

Bott, N. T., Bettcher, B. M., Yokoyama, J. S., Frazier, D. T., Wynn, M., Karydas, A., Yaffe, K., \& Kramer, J. H. (2017). Youthful processing speed in older adults: Genetic, biological, and behavioral predictors of cognitive processing speed trajectories in aging. Frontiers in Aging Neuroscience, 9. https://doi.org/10.3389/fnagi.2017.00055

Brown, G. C. (2015). Living too long: The current focus of medical research on increasing the quantity, rather than the quality, of life is damaging our health and harming the economy. EMBO Reports, 16(2), 137-141. https://doi.org/10.15252/embr.201439518

Buettner, D., \& Skemp, S. (2016). Blue Zones: Lessons from the world's longest lived. American Journal of Lifestyle Medicine, 10(5), 318-321. https://doi.org/10.1177/1559827616637066

Cabeza, R., Albert, M., Belleville, S., Craik, F. I. M., Duarte, A., Grady, C. L., Lindenberger, U., Nyberg, L., Park, D. C., Reuter-Lorenz, P. A., Rugg, M. D., Steffener, J., \& Rajah, M. N. (2018). Maintenance, reserve and compensation: The cognitive neuroscience of healthy ageing. Nature Reviews Neuroscience, 19(11), 701-710. https://doi.org/10.1038/s41583-018-0068-2

Centrum pro studium dlouhověkosti a dlouhodobé péče FHS UK (CELLO). (b.r.). https://cello-ilc.fhs.cuni.cz/CEL-1.html

Cook Maher, A., Kielb, S., Loyer, E., Connelley, M., Rademaker, A., Mesulam, M.-M., Weintraub, S., McAdams, D., Logan, R., \& Rogalski, E. (2017). Psychological wellbeing in elderly adults with extraordinary episodic memory. PloS One, 12(10), e0186413. https://doi.org/10.1371/journal.pone.0186413

Cowgill, D. O., \& Holmes, L. D. (1972). Summary and conclusions: A theory in review. In D. O. Cowgill \& L. D. Holmes (Ed.), Aging and modernization (s. 305-323). AppletonCentury-Crofts.

Čepelka, O. (2018). Od AAI k HAI? Měření aktivního stárnutí pomocí složených indexů. In Stárnutí 2018: Sborník př́spěvků ze 4. Gerontologické mezioborové konference (s. 1016). Univerzita Karlova, 3. lékařská fakulta. http://www.konferencestarnuti.cz/files/Starnuti_2018_sbornik.pdf

Červenková, M., Heissler, R., \& Kopeček, M. (2020). Stability of memory SuperAgers over 3 years. PsyCh Journal, 9(1), 147-149. https://doi.org/10.1002/pchj.313

Dominy, S. S., Lynch, C., Ermini, F., Benedyk, M., Marczyk, A., Konradi, A., Nguyen, M., Haditsch, U., Raha, D., Griffin, C., Holsinger, L. J., Arastu-Kapur, S., Kaba, S., Lee, A., Ryder, M. I., Potempa, B., Mydel, P., Hellvard, A., Adamowicz, K., ... Potempa, J. (2019). Porphyromonas gingivalis in Alzheimer's disease brains: Evidence for disease causation and treatment with small-molecule inhibitors. Science Advances, 5(1), eaau3333. https://doi.org/10.1126/sciadv.aau3333 
Duncan, D. E. (2012, srpen 25). How long do you want to live? New York Times, SR4.

EU Science Hub. (2020). EU burden from non-communicable diseases and key risk factors. https://ec.europa.eu/jrc/en/health-knowledge-gateway/societal-impacts/burden

Federal Statistical Office. (2016). Older people in Germany and the EU. Statistisches Bundesamt.

Finkel, D., Andel, R., Gatz, M., \& Pedersen, N. L. (2009). The role of occupational complexity in trajectories of cognitive aging before and after retirement. Psychology and Aging, 24(3), 563-573. https://doi.org/10.1037/a0015511

Flynn, J. R. (1987). Massive IQ gains in 14 nations: What IQ tests really measure. Psychological Bulletin, 101(2), 171-191. https://doi.org/10.1037/0033-2909.101.2.171

Ganguli, M., Bilt, J. V., Lee, C.-W., Snitz, B. E., Chang, C.-C. H., Loewenstein, D. A., \& Saxton, J. A. (2010). Cognitive test performance predicts change in functional status at the population level: The MYHAT Project. Journal of the International Neuropsychological Society, 16(5), 761-770. https://doi.org/10.1017/S1355617710000561

Gefen, T., Peterson, M., Papastefan, S. T., Martersteck, A., Whitney, K., Rademaker, A., Bigio, E. H., Weintraub, S., Rogalski, E., Mesulam, M.-M., \& Geula, C. (2015). Morphometric and histologic substrates of cingulate integrity in elders with exceptional memory capacity. The Journal of Neuroscience: The Official Journal of the Society for Neuroscience, 35(4), 1781-1791. https://doi.org/10.1523/JNEUROSCI.2998-14.2015

Goode, R. C. (1978). A Guide to Personal Fitness. Queen's Printer.

Gottesman, R. F., Albert, M. S., Alonso, A., Coker, L. H., Coresh, J., Davis, S. M., Deal, J. A., McKhann, G. M., Mosley, T. H., Sharrett, A. R., Schneider, A. L. C., Windham, B. G., Wruck, L. M., \& Knopman, D. S. (2017). Associations between midlife vascular risk factors and 25-year incident dementia in the atherosclerosis risk in communities (ARIC) cohort. JAMA Neurology, 74(10), 1246. https://doi.org/10.1001/jamaneurol.2017.1658

Hack, E. E., Dubin, J. A., Fernandes, M. A., Costa, S. M., \& Tyas, S. L. (2019). Multilingualism and dementia risk: Longitudinal analysis of the Nun Study. Journal of Alzheimer's Disease, 71(1), 201-212. https://doi.org/10.3233/JAD-181302

Hahn, C., \& Lee, C. U. (2019). A brief review of paradigm shifts in prevention of Alzheimer's disease: From cognitive reserve to precision medicine. Frontiers in Psychiatry, 10, 786. https://doi.org/10.3389/fpsyt.2019.00786

Harrison, T. M., Maass, A., Baker, S. L., \& Jagust, W. J. (2018). Brain morphology, cognition, and $\beta$-amyloid in older adults with superior memory performance. Neurobiology of Aging, 67, 162-170. https://doi.org/10.1016/j.neurobiolaging.2018.03.024

Harrison, T. M., Weintraub, S., Mesulam, M.-M., \& Rogalski, E. (2012). Superior memory and higher cortical volumes in unusually successful cognitive aging. Journal of the International Neuropsychological Society: JINS, 18(6), 1081-1085. https://doi.org/10.1017/S1355617712000847

Iacono, D., Markesbery, W. R., Gross, M., Pletnikova, O., Rudow, G., Zandi, P., \& Troncoso, J. C. (2009). The Nun Study: Clinically silent AD, neuronal hypertrophy, and linguistic skills in early life. Neurology, 73, 665-673. https://doi.org/10.1212/WNL.0b013e3181b01077

Johnson, T. E. (1987). Aging can be genetically dissected into component processes using long-lived lines of Caenorhabditis elegans. Proceedings of the National Academy of Sciences, 84(11), 3777-3781. https://doi.org/10.1073/pnas.84.11.3777 
Josefsson, M., Sundström, A., Pudas, S., Nordin Adolfsson, A., Nyberg, L., \& Adolfsson, R. (2019). Memory profiles predict dementia over 23-28 years in normal but not successful aging. International Psychogeriatrics, 1-9. https://doi.org/10.1017/S1041610219001844

Kopeček, M., Frydrychová, Z., Heissler, R., \& Georgi, H. (2020). Kognitivně svěží osmdesátníci - Superagers. Psychiatrie pro praxi, 21(3), 112-115.

Kř́žz, J. (2016). Lost Years of Healthy Life in the Czech Republic. Hygiena, 61(2), 88-90. https://doi.org/10.21101/hygiena.a1451

Kyu, H. H., Abate, D., Abate, K. H., Abay, S. M., Abbafati, C., Abbasi, N., Abbastabar, H., Abd-Allah, F., Abdela, J., Abdelalim, A., Abdollahpour, I., Abdulkader, R. S., Abebe, M., Abebe, Z., Abil, O. Z., Aboyans, V., Abrham, A. R., Abu-Raddad, L. J., AbuRmeileh, N. M. E., ... Murray, C. J. L. (2018). Global, regional, and national disabilityadjusted life-years (DALYs) for 359 diseases and injuries and healthy life expectancy (HALE) for 195 countries and territories, 1990-2017: A systematic analysis for the Global Burden of Disease Study 2017. The Lancet, 392(10159), 1859-1922. https://doi.org/10.1016/S0140-6736(18)32335-3

Lang, F. R., Baltes, P. B., \& Wagner, G. G. (2007). Desired lifetime and end-of-life desires across adulthood from 20 to 90: A dual-source information model. The Journals of Gerontology. Series B, Psychological Sciences and Social Sciences, 62(5), P268-276.

Life Expectancy of the World Population. (b.r.). Worldometers. https://www.worldometers.info/demographics/life-expectancy/

Lindquist, K. A., Satpute, A. B., Wager, T. D., Weber, J., \& Barrett, L. F. (2016). The Brain Basis of Positive and Negative Affect: Evidence from a Meta-Analysis of the Human Neuroimaging Literature. Cerebral Cortex, 26(5), 1910-1922. https://doi.org/10.1093/cercor/bhv001

Lowry, K. A., Vallejo, A. N., \& Studenski, S. A. (2012). Successful aging as a continuum of functional independence: Lessons from physical disability models of aging. Aging and Disease, 3(1), 5-15.

Lu, B. (2017). Redesigning Long-Term Senior Care: Design Solutions to Facilitate Different Levels of Care Needs in Senior Housing-Using Hong Kong's Latest Senior Housing as Example. 1307-1324.

https://wsbe17hongkong.hk/_bin/ckfinder/userfiles/files/Paper/P_1307-

1324\%20Redesigning\%20Long-Term\%20Senior\%20Care.pdf

Lynn, R. (2013). Who discovered the Flynn effect? A review of early studies of the secular increase of intelligence. Intelligence, 41(6), 765-769.

https://doi.org/10.1016/j.intell.2013.03.008

Mana, J., \& Bezdicek, O. (in press). Cognition in successful aging: Systematic review and future directions. Clinical Gerontologist.

Mander, B. A., Winer, J. R., \& Walker, M. P. (2017). Sleep and human aging. Neuron, 94(1), 19-36. https://doi.org/10.1016/j.neuron.2017.02.004

Mapstone, M., Lin, F., Nalls, M. A., Cheema, A. K., Singleton, A. B., Fiandaca, M. S., \& Federoff, H. J. (2017). What success can teach us about failure: The plasma metabolome of older adults with superior memory and lessons for Alzheimer's disease. Neurobiology of Aging, 51, 148-155. https://doi.org/10.1016/j.neurobiolaging.2016.11.007

Marchant, N. L., \& Howard, R. J. (2015). Cognitive debt and Alzheimer's disease. Journal of Alzheimer's Disease, 44(3), 755-770. https://doi.org/10.3233/JAD-141515 
Morris, M. C., Tangney, C. C., Wang, Y., Barnes, L. L., Bennett, D., \& Aggarwal, N. (2014). MIND diet more predictive than DASH or Mediterranean diet scores. Alzheimer's \& Dementia, 10, P166-P166. https://doi.org/10.1016/j.jalz.2014.04.164

Morris, M. C., Tangney, C. C., Wang, Y., Sacks, F. M., Barnes, L. L., Bennett, D. A., \& Aggarwal, N. T. (2015). MIND diet slows cognitive decline with aging. Alzheimer's \& Dementia, 11(9), 1015-1022. https://doi.org/10.1016/j.jalz.2015.04.011

Muramatsu, N., \& Akiyama, H. (2011). Japan: Super-Aging Society Preparing for the Future. The Gerontologist, 51(4), 425-432. https://doi.org/10.1093/geront/gnr067

Neuropathology Group of the Medical Research Council Cognitive Function and Ageing Study(MRC CFAS). (2001). Pathological correlates of late-onset dementia in a multicentre, community-based population in England and Wales. The Lancet, 357(9251), 169-175. https://doi.org/10.1016/S0140-6736(00)03589-3

Nyberg, L., \& Pudas, S. (2019). Successful memory aging. Annual Review of Psychology, 70, 219-243. https://doi.org/10.1146/annurev-psych-010418-103052

Passarino, G., De Rango, F., \& Montesanto, A. (2016). Human longevity: Genetics or lifestyle? It takes two to tango. Immunity \& Ageing, 13(1), 12. https://doi.org/10.1186/s12979-016-0066-z

Rogalski, E. J., Gefen, T., Cook, A., Bigio, E. H., Weintraub, S., Geula, C., \& Mesulam, M.M. (2015). Neurobiologic features of cognitive superaging. Alzheimer's \& Dementia, 11(7), P257. https://doi.org/10.1016/j.jalz.2015.07.323

Rogalski, E. J., Gefen, T., Mao, Q., Connelly, M., Weintraub, S., Geula, C., Bigio, E. H., \& Mesulam, M.-M. (2018). Cognitive trajectories and spectrum of neuropathology in SuperAgers: The first 10 cases. Hippocampus. https://doi.org/10.1002/hipo.22828

Rogalski, E. J., Gefen, T., Shi, J., Samimi, M., Bigio, E., Weintraub, S., Geula, C., \& Mesulam, M.-M. (2013). Youthful memory capacity in old brains: Anatomic and genetic clues from the Northwestern SuperAging Project. Journal of Cognitive Neuroscience, 25(1), 29-36. https://doi.org/10.1162/jocn_a_00300

Rowe, J. W., \& Kahn, R. L. (1987). Human aging: Usual and successful. Science (New York, N.Y.), 237(4811), 143-149. https://doi.org/10.1126/science.3299702

Saint Martin, M., Sforza, E., Barthélémy, J. C., Roche, F., Lefèvre, P., Liénard, G., \& Thomas-Anterion, C. (2017). Long-lasting active lifestyle and successful cognitive aging in a healthy elderly population: The PROOF cohort. Revue Neurologique, 173(10), 637644. https://doi.org/10.1016/j.neurol.2017.05.009

Salthouse, T. A. (2015). Implications of the Flynn effect for age-cognition relations. Intelligence, 48, 51-57. https://doi.org/10.1016/j.intell.2014.10.007

Schneider, J. A., \& Viswanathan, A. (2019). The time for multiple biomarkers in studies of cognitive aging and dementia is now. Neurology, 92(12), 551-552. https://doi.org/10.1212/WNL.0000000000007120

Snowdon, D. A. (2003). Healthy aging and dementia: Findings from the Nun Study. Annals of Internal Medicine, 139(5_Part_2), 450. https://doi.org/10.7326/0003-4819-139-5_Part_2200309021-00014

Stern, Y. (2002). What is cognitive reserve? Theory and research application of the reserve concept. Journal of the International Neuropsychological Society, 8(3), 448-460. https://doi.org/10.1017/S1355617702813248 
Sun, F. W., Stepanovic, M. R., Andreano, J., Barrett, L. F., Touroutoglou, A., \& Dickerson, B. C. (2016). Youthful brains in older adults: Preserved neuroanatomy in the default mode and salience networks contributes to youthful memory in superaging. Journal of Neuroscience, 36(37), 9659-9668. https://doi.org/10.1523/JNEUROSCI.1492-16.2016

Štěpánková, H., Bezdíček, O., Nikolai, T., Horáková, K., Lukavský, J., \& Kopeček, M. (2015). Zpráva o projektu Národní normativní studie kognitivních determinant zdravého stárnutí. E-psychologie, 9(1), 43-46.

Taffet, G. E. (2019). Normal Aging. In K. E. Schmader, Up to Date. https://www.uptodate.com/contents/normal-aging

UN, Department of Economic and Social Affairs, Population Division. (2019a). World Population Ageing 2019: Highlights (ST/ESA/SER.A/430). United Nations. https://www.un.org/en/development/desa/population/publications/pdf/ageing/WorldPopul ationAgeing2019-Highlights.pdf

UN, Department of Economic and Social Affairs, Population Division. (2019b). World Population Prospects 2019: Highlights (ST/ESA/SER.A/423). United Nations. https://population.un.org/wpp/Publications/Files/WPP2019_Highlights.pdf

UNECE / European Commission. (2019). "2018 Active Ageing Index: Analytical Report”, Report prepared by Giovanni Lamura and Andrea Principi under contract with the United Nations Economic Commission for Europe (Geneva), co-funded by the European Commission's Directorate General for Employment, Social Affairs and Inclusion (Brussels). http://www.unece.org/fileadmin/DAM/pau/age/Active_Ageing_Index/Stakeholder_Meeti ng/ACTIVE_AGEING_INDEX_TRENDS_2008-2016_web_cover_reduced.pdf

Vaarama, M. (2009). Care-related quality of life in old age. European Journal of Ageing, 6(2), 113-125. https://doi.org/10.1007/s10433-009-0115-y

Valaoras, V. G. (1950). Patterns of aging of human populations. The Social and Biological Challenge of Our Aging Population, Proceedings of the Eastern States Health Education Conference, 67-85.

Wang, X., Sun, G., Feng, T., Zhang, J., Huang, X., Wang, T., Xie, Z., Chu, X., Yang, J., Wang, H., Chang, S., Gong, Y., Ruan, L., Zhang, G., Yan, S., Lian, W., Du, C., Yang, D., Zhang, Q., ... Geng, M. (2019). Sodium oligomannate therapeutically remodels gut microbiota and suppresses gut bacterial amino acids-shaped neuroinflammation to inhibit Alzheimer's disease progression. Cell Research, 29(10), 787-803. https://doi.org/10.1038/s41422-019-0216-x

World Health Organization. (2015). World report on ageing and health. World Health Organization. https://apps.who.int/iris/bitstream/handle/10665/186463/9789240694811_eng.pdf;jsessio nid=78A28FEF44CC13B2FF26777130E24ACA? sequence $=1$

World Health Organization. (2019). Risk reduction of cognitive decline and dementia: WHO guidelines. World Health Organization. https://apps.who.int/iris/bitstream/handle/10665/312180/9789241550543-eng.pdf

Yu, J., Collinson, S. L., Liew, T. M., Ng, T.-P., Mahendran, R., Kua, E.-H., \& Feng, L. (2019). Super-cognition in aging: Cognitive profiles and associated lifestyle factors. Applied Neuropsychology: Adult, 1-7. https://doi.org/10.1080/23279095.2019.1570928

Zahodne, L. B., Stern, Y., \& Manly, J. J. (2015). Differing effects of education on cognitive decline in diverse elders with low versus high educational attainment. Neuropsychology, 29(4), 649-657. https://doi.org/10.1037/neu0000141 
Zullo, J. M., Drake, D., Aron, L., O’Hern, P., Dhamne, S. C., Davidsohn, N., Mao, C.-A., Klein, W. H., Rotenberg, A., Bennett, D. A., Church, G. M., Colaiácovo, M. P., \& Yankner, B. A. (2019). Regulation of lifespan by neural excitation and REST. Nature, 574(7778), 359-364. https://doi.org/10.1038/s41586-019-1647-8

\section{Údaje o autorkách}

PhDr. Hana Georgi, Ph.D. je zakládající členkou Neurotrend, z.s. a odborné sekce geropsychologie Českomoravské psychologické společnosti. Řadu let působila jako vědecká pracovnice $\mathrm{v}$ projektech zaměřených na otázky stárnutí a kognice.

\section{Kontaktní údaje:}

Adresa: Neurotrend, z.s., Haštalská 27, Praha 1

E-mail: hanageorgi.cz@gmail.com

Mgr. Zuzana Frydrychová je studentkou doktorského studia klinické psychologie na Filozofické fakultě Univerzity Karlovy. Je výzkumným pracovníkem v Národním ústavu duševního zdraví. Dále působí jako psycholog v předatestační prrípravě na Klinice rehabilitačního lékařství a Neurologické klinice Všeobecné fakultní nemocnice v Praze.

\section{Kontaktní údaje:}

Adresa: Filozofická fakulta Univerzity Karlovy, Celetná 20, 11000 Praha 1

Kontakt: frydychova.zuzka@gmail.com

Georgi, H., \& Frydrychová, Z. (2020). SuperAging - společnost a lidé: úvod do problematiky. E-psychologie, 14(1), 55-69. https://doi.org./10.29364/epsy.366 